\title{
The Surgeon
}

\author{
Domingo M. Braile
}

São José do Rio Preto, SP

Has it all been worthwhile? I do not know. Many of my childhood friends have luxurious lives, with seaside homes, wonderful boats, huge farms, beautiful homes, brand new imported cars. Have the many years of uninterrupted studies, throughout my entire life been worth it? Have the endless hours spent at the bedside of dying patients, counting every single drop of urine, dreading to check the drainage vial, which continues to fill up with blood, despite all the efforts and prayers for the hemorrhage to stop, been worth it? Has it been worthwhile to keep on looking, filled with anguish, at the patient's blood pressure monitor, which shows continuously lower values that will not increase, not even a tiny bit just to cheer us up? Has it been worthwhile to keep on looking at the thermometer as the fever goes up. . . and up, indicating that the drugs had not been effective in fighting the infection that consumes our patient and friend? Has this life, lived between the dilemma of saving people's lives or the frustration for not having the supreme power to change the natural course of diseases, which belongs to God, been worth it? I have just called the ICU (Intensive Care Unit). Mr. Souza's pressure is normal, he is not bleeding and he is awake. He can move his limbs. It is 4:00 a.m. and maybe I will be able to go to sleep now! Mr. Souza was visiting in town. He had come from far away; his home was over one thousand kilometers away. He was here on business, performing his daily activities. Suddenly, he felt an acute and strong pain in his chest, spreading to his upper left limb and his chin. He felt as if someone were trying to pull out his arm. He felt death coming soon. The pain was unbearable, and he could hardly breathe. He was going to die away from home, with no relatives or friends to share his anguish. He made the decision to go to the emergency room of a hospital. Maybe people there would be able to save him....When I saw him, his lips were purple, and his face showed his pain and begged for something. How can one not be touched by a picture like this, despite the many years

Mailing address: Domingo M. Braile - Av. Juscelino Kubitschek, 3101 15091-450 - São José do Rio Preto, SP - Brazil -

E-mail: webmaster@braile.com.br of professional life, which should have made us less sensitive after having lived through intensive pain for such a long time? We had to be quick. Time was going by, and each lost minute reduced dramatically the survival chances of this unfortunate man, whose name I did not even know at the time. I was not alone. Eight dedicated colleagues were part of the patient's drama and my own private drama. I wanted to save his life so badly! An alarm sounded.... Cardiac arrest! Ventricular fibrillation, informed the monitor. Were we going to lose the patient? We maintained his blood pressure with cardiac massage, through which our hands transmitted energy for the blood to continue pumping. Finally, the defibrillator kissed the patient's heart, with a shock of thousands of volts, bringing back the soul that was leaving him. Conditions stabilized a little, and it was possible to operate the patient. His name was still unknown to us. The saphenous vein bypass grafts and the mammary artery grafts brought new blood to the strained arteries of his heart, which was immediately thankful, and pumped vigorously again. I would not be exaggerating if I said that the heart now pumped with happiness, at the same pace as our dreams for having helped God save one more life. Mr. Souza is now awake, his blood pressure is normal, he breathes peacefully, he is not bleeding... . It is 4:00 a.m. .. .It has been worth it! Unfortunately, it is not always like this. Sometimes, despite all the effort and dedication, patients die, and we feel like we have been stabbed from behind! At times like this, we have to be humble and understand that we cannot fight against the Creator's plans, He who gives each individual a mission. I end this with the words of a dear friend, to whom I am forever thankful for the kind words with which he consoled me at a difficult time in our lives.

"Doctor, I am immensely thankful for your effort... when you held my wife's heart in your hands, for the third time (in the last 32 years). There was nothing to be done, Doctor. Above us, and all of the problems we have to face, there is a God. And Doctor, He has granted you the ability to save lives. How many lives you have saved! Thanks to you, I now have a family. Thanks to your dedication, your energy and love for the human being."

As you can see, dear readers, in fact. . .it has all been worthwhile. 